Article

\title{
Copyright User Rights and Remedies: An Access to Justice Perspective
}

\author{
Pascale Chapdelaine \\ Faculty of Law University of Windsor, 401 Sunset Ave, Windsor, ON N9B 3P4, Canada; \\ Pascale.Chapdelaine@uwindsor.ca
}

Received: 19 April 2018; Accepted: 11 June 2018; Published: 27 June 2018

\begin{abstract}
In contemporary copyright law, there is an ongoing debate around the nature and scope of the rights users should have to copyright works, exacerbated by ongoing technological developments. Within that debate, this article queries the value of looking at the remedies users may have against copyright holders restricting their legitimate uses of works, as a means to further elucidate the nature and scope of user rights. While there is some value in looking at remedies to situate copyright user rights, an access to justice perspective to rights and remedies suggests that such approach may be too limiting with respect to the position of potential claimants in a legal system. On that basis, this paper identifies structural deficiencies of copyright user rights and proposes an analytical framework towards achieving greater "justice for users" both in the realm of public law and private law.
\end{abstract}

Keywords: copyright; user rights; remedies; access to justice; human rights; freedom of expression; access to knowledge; personal property; technological protection measures

\section{Introduction: The Uncertain Contours of Copyright User Rights}

Users of works protected by copyright (books, musical recordings, films, video games, computer programs) have rights to those works through various means: the personal property in a copy of a copyright work they buy, a license or services contract, or generally through the effect of copyright law (e.g., exceptions to copyright infringement such as fair dealing or fair use). That much should be hardly controversial. What is more controversial to some or at best uncertain to others, is the scope of those user rights including what is traditionally referred to as exceptions to copyright infringement. This is due in great part to copyright law having been predominantly centered on the exclusive rights of authors and copyright holders. It is also due to the complex interaction between personal property, contract and copyright law and to diverging opinions about the purpose of copyright law, vis-à-vis creators, the ones who access and use their creations, and more generally with respect to the public interest (Chapdelaine 2017, pp. 13-19, 31,32). The controversy or uncertainty around what user rights are or should be is exacerbated by incessant technological developments affecting the creation, protection of works, as well as their dissemination and access by users and the public.

As it concerns exceptions to copyright infringement, starting with CCH Canadian Ltd. $v$ Law Society of Upper Canada $[\mathrm{CCH}]^{1}$, the Supreme Court of Canada has repeatedly stated that such exceptions are not mere loopholes in Canada's Copyright Act $[C C A]:^{2}$ they are copyright users' rights. ${ }^{3}$ Affirming

2004 SCC 13 [CCH].

Copyright Act, RSC 1985, c C-42 [CCA].

CCH, supra note 1 at para 48; Society of Composers Authors and Music Publishers of Canada v Bell Canada, 2012 SCC 36 at para 11 [Bell Canada]; Alberta (Education) v Canadian Copyright Licensing Agency (Access Copyright), 2012 SCC 37 at para 22 [Alberta]; Reference re Broadcasting Regulatory Policy CRTC 2010-167 and Broadcasting Order CRTC 2010-168, 2012 SCC 68 at paras 56ff [CRTC]. 
that copyright users have rights under the $C C A$ goes hand in hand with a broader commitment by law and policy makers towards maintaining a balance among competing interests in copyright law. ${ }^{4}$ The Supreme Court of Canada's qualification of exceptions to copyright infringement as user rights contrasts with courts in other jurisdictions, including the US and France, that have typically referred to exceptions to copyright infringement as defenses that cannot form the basis of a legal claim. ${ }^{5}$

This jurisprudential development by the Supreme Court of Canada has led to an important body of scholarship in Canada and worldwide. ${ }^{6}$ While most scholars welcomed the Supreme Court statement that copyright users had rights, making Canada the champion of "rights of users to balance copyright, ${ }^{\prime 7}$ a perplexing aspect of this jurisprudential development is that it is far from clear that users have rights per se under the CCA, at least in the Hohfeldian sense of jural correlatives: i.e., a right implies that someone has a duty towards it (Hohfeld 1913, 1917) (Chapdelaine 2013, pp. 28-30). True, the statement in $\mathrm{CCH}$ that exceptions to copyright infringement are rights has introduced an important rule of interpretation that expanded the scope of those exceptions and by the same token narrowed the scope of the copyright grant, with greater regard for the interests of copyright users in copyright law (Chapdelaine 2013, pp. 31-32).

At a minimum, under the current understanding of exceptions to copyright infringement, they would qualify as privilege in the Hohfeldian sense of the term. ${ }^{8}$ An exception or defense to copyright infringement qualifies as a privilege to the extent that it allows a user to perform certain acts without authorization, but does not require copyright holders to facilitate the exercise of these acts (e.g., when constrained by a technological protection measure (TPM)). By contrast, if users have the power in law to require copyright holders to facilitate the performance of acts that are allowed through exceptions to copyright infringement, the said exceptions would then be more properly characterized as right (in Hohfeldian terms).

4 Théberge v Gallerie d'art du petit Champlain Inc., 2002 SCC 34 at para 30 [Théberge]; CCH, supra note 1 at paras $10,14-36$ (in particular 23-24), 48; Bell Canada, supra note 3 at para 9. Public discourse on the need to balance the interests of copyright holders, of users, and the public was particularly prevalent in the last major Canadian copyright law reform that led to the entry into force in 2012 of the Copyright Modernization Act, SC 2012, c 20, with a Government website devoted to copyright reform titled "www.balancedcopyright.gc.ca" (website no longer accessible).

5 See e.g., Campbell v Acuff-Rose Music, Inc., 510 US 569 at 590 (1994), fair use being referred to as an affirmative defense; Trib. gr. inst. 5 $5^{\mathrm{e}}$ Paris, 10 January 2006, Christophe R., UFC Que Choisir/Warner Music France, Fnac (2006) JurisData: 2006-292685; on appeal CA Paris, 20 June 2007, Fnac Paris/UFC Que Choisir et autres (2007) Juris Data 2007-337236; confirmed by the Cour de cassation: Cass civ 1 ${ }^{\text {re }}, 27$ November 2008, UFC Que Choisir/Fnac, Warner music France (2008) JurisData 2008-046005; CA, Paris, 4 April 2007, Studio Canal et al. v S Perquin and Union fédérale des consommateurs Que choisir, Gaz Pal 18/07/2007 No 199, 23; confirmed by the Cour de Cassation: Cass civ $1^{\text {re }}, 19$ June 2008, (2008) Bull civ I No 177. Given the introduction in 2009 of article L331-31 in France's Code de Propriété Intellectuelle [France CPI] of a procedure facilitating the resolution of complaints by persons deprived of the exercise of some exceptions to copyright infringement, the statement that exceptions to copyright infringement cannot form the basis of a claim no longer stands. Courts in the US have occasionally referred to fair use or other exception as a "user right": see e.g., Lenz v. Universal Music Corp, 815 F.3d 1145 (9 ${ }^{\text {th }}$ Cir. 2016) holding that fair use is a right and therefore "authorized by law" in the context of a notice and take-down procedure pursuant to US Digital Millenium Copyright Act; other US courts have referred to exceptions to copyright infringement as a "user right" with no further elaboration on the subject: see e.g., Whelan Associates Inc v Jaslow Dental Laboratory Inc., 797 F (2d) 1222 (3rd Cir 1984); Bateman v Mnemonics Inc., 79 F (3d) 1532 at no 22 (11th Cir 1996); Suntrust Bank v Houghton Mifflin Co., 268 F (3d) 1257 at no. 3 (11th Cir 2001); US v Elcom Ltd., 203 F Supp (2d) 1111 at 1119 (ND Cal 2002); 321 Studios v Metro Goldwyn Mayer Studios Inc., 307 F Supp (2d) 1085 (ND Cal 2004). For a discussion on recent judgments by the Isareli Supreme Court and its treatment of fair use see: Elkin-Koren (2016, pp. 37-38).

6 See e.g., Gervais (2004); Tawfik (2005a, 2005b); Drassinower (2005); Scassa (2005); Craig (2005); D'Agostino (2008, p. 357); Craig (2011, pp. 155-202, in particular pp. 168, 170-74, 179); Katz (2013); Chapdelaine (2013); Tawfik (2013); Chapdelaine (2017); Craig (2017).

7 D'Agostino, supra note 6, p. 357. See however Craig (2017, pp. 62-64, 69, 73), (warning against rights rhetoric as narrowing the focus on copyright holders and user entitlements, and being potentially "inhospitable to the very consideration that ought to inform copyright law" by missing out on the broader dimension of social creativity, culture and a vibrant public domain, while at the same time recognizing the intrinsic power of the language of rights as possibly enabling social change for the benefit of users of copyright works).

8 i.e., that exceptions to copyright infringement are privileges to the extent that they confer the ability to do something with no correlation from anyone obligated towards this ability: Hohfeld (1917); Hohfeld (1913). See also Chapdelaine (2013, pp. 28-30). 
In addition to the uncertainty that surrounds the nature of exceptions to copyright infringement, whether copyright holders may contract out of those exceptions is an unsettled area of law (Chapdelaine 2013, pp. 37-38). Unlike other jurisdictions, ${ }^{9}$ the $C C A$ is silent on that point. While some commentators hold that no definitive conclusion can be derived from this statutory silence, ${ }^{10}$ others argue that the mandatory nature of exceptions to copyright infringement may depend on the underlying justification of the exception, ${ }^{11}$ or that silence could mean that exceptions to copyright infringement may be set aside by contract. ${ }^{12}$ In a nutshell, the effect contracts may have on exceptions to copyright infringement is not clear and this legal uncertainty is less than desirable for copyright users and copyright law more generally.

Referring to exceptions to copyright infringement as "copyright user rights" carries undeniable rhetorical force and power by recognizing for users something that the law has for long acknowledged and meticulously carved out for copyright holders. ${ }^{13}$ Beyond justness in characterization or distinctions between Hohfeldian rights and privileges (and the usefulness of this distinction when looking at user remedies), the language of rights when describing what users can do without the permission of copyright holders sets a new trajectory for copyright law. It gives prominence to users as being equally important to attain the objectives of copyright law, as is the declared objective to incent authors to create by conferring exclusive rights to them. ${ }^{14}$

One way to better understand copyright user rights may be to ask what remedies users have against copyright holders when they are denied access to allegedly legitimate uses of a copyright work (e.g., uses they would be normally allowed to do under copyright law but which are restricted either through a TPM or by contract). Here, "remedies" refers primarily to court orders (e.g., to pay damages, specific performance or injunctions) ${ }^{15}$ which is a common understanding of remedies when theorizing about their relationship to rights (Smith 2010, pp. 34-35). ${ }^{16}$ A declaratory judgment would also fall in the category of remedies (Wright 2010, p. 281). A declaratory relief is what the Law Society of Upper Canada as defendant had resorted to as a counterclaim to non-infringement of copyright in the lower

9 See e.g., France CPI, supra note 5, art L 122-6-1 in fine, listing exceptions to copyright infringement that are mandatory; Belgium Wetboek van economisch recht/Code de droit économique, art XI.193, listing exceptions to copyright infringement relating to computer programs that are mandatory; Copyright, Designs and Patents Act 1988, c 48, (UK), see e.g., ss 29 (4b) (fair dealing for purpose of research and private study) 29A (5) Copies for text and data analysis for non-commercial research) 30(1ZA)(4) (quotations) 30A(2) (caricature, parody or pastiche) [UKCDPA].

10 Guibault (2002) (having conducted an extensive comparative study on the mandatory nature of exceptions to copyright infringement).

11 See De Werra (2003, pp. 335-36), (e.g., exceptions that are justified by fundamental rights may not be overridden by contract, while the ones that are justified on other grounds, e.g., public policy considerations may); see also Dusollier (2007, pp. 507-9).

12 See Australia Commonwealth (2013) at para 20.26, acknowledging that there is no certainty on that matter; see also Australian Government, Department of Communication and the Arts (2018, pp. 15-18), (public consultation about copyright legislative reform to address the issue of contracting out of exceptions to copyright infringement). US courts have explicitly held exceptions to copyright infringement may be waived by contract. See e.g., Bowers v Baystate Techs, Inc., $320 \mathrm{~F}$ (3d) 1317 at 1325 (Fed Cir 2003); Davidson E Associates Inc., et al. v Internet Gateway, 334 F Supp (2d) 1164 (ED Mo 2004).

13 Craig (2017, pp. 64-70), (offering a critique of user rights rhetoric while acknowledging the power of rights language, referring to the insights of feminist and critical race theory responses to critical legal studies' attacks on rights-based reasoning).

14 Elkin-Koren (2016, p. 36); Elkin-Koren (2017, p. 132), (exploring how a user-rights approach posits users as active participants promoting creation, dissemination and use of cultural works rather than "parasites" benefiting unjustly from limits on author's rewards, and arguing that uses that promote the objectives of copyright law should be considered rights and not mere legal defenses).

15 An inquiry into remedies of copyright users also involves looking at procedures of administrative bodies that seek to facilitate access to copyright works between the right holder and the user when the user faces obstacles to such uses, as is the case in France and in the UK: see Part 2 below.

16 For a discussion on the monist and dualist views of rights and remedies in the common law tradition, see Dedek (2010, pp. 86-89). 
court levels in $\mathrm{CCH}^{17}$ and more recently what York University sought in a copyright infringement lawsuit opposing it to the Canadian Copyright Licensing Agency. ${ }^{18}$

Investigating the nature and scope of user rights by looking at the remedies users have seems $a$ priori to be a legitimate pursuit. After all, the centuries old Latin phrase ubi jus ibi remedium stands for the idea that there are no rights without remedies. This Latin maxim reflects a monist view whereby the remedy actually defines the right (Dedek 2010, pp. 86-87). Without having to take the extreme view shared by some that the right is swallowed by the remedies or that the right is in fact the remedy (Dedek 2010, pp. 86-87), the relationship between rights and remedies allows for a better understanding of the various conceptions of rights we may have. The availability of a remedy shapes to some extent the nature of a particular right, which when violated, gives access to it and vice versa. ${ }^{19}$

This article takes a critical look at what remedies, as viewed in the traditional sense may bring to the discussion about the rights users (should) have to copyright works, through the lens of access to justice. ${ }^{20}$ I argue that querying what remedies copyright users have is asking the wrong question too soon. Just as seeking to improve access to justice by adopting a too narrow focus, e.g., looking primarily at access to courts, will likely produce limited results (and may even accentuate disparities further between the haves and the have nots instead of addressing the root causes of justice deficits), similarly, looking at copyright user rights through the remedies they may have against copyright holders will do little at this stage, until we address the more fundamental substantive and structural problems that concern copyright users. If anything, the limited remedies (or absence thereof) that copyright users have against copyright holders blocking access to otherwise legitimate uses only reinforce the idea of the malleability and volatility of copyright user rights in our current legal system.

This article discusses the broader implications of user rights from an access to justice perspective, beyond the remedies copyright users may have when they are constrained in legitimate uses of a work. I focus on Canada with reference to other jurisdictions and the international landscape. Part 2 provides a summary of the limited remedies users currently have against copyright holders when they are blocked from making legitimate uses of copyright works. Part 3 looks at the sphere of inquiry of an access to justice perspective for authors, copyright holders, and copyright users, with a predominant focus on the latter. In doing so, I lay the ground of what we might mean by "justice for users", and about the group(s) of users that we have in mind. I also discuss why traditional remedies play a limited role in bolstering copyright user rights at this point in time. I suggest a path of legal reform toward what would lead to stronger rights for copyright users, by re-conceptualizing the privileges and powers copyright holders and users enjoy on a copyright work. I conclude by reflecting on other areas of inquiry left unexplored at the intersection of copyright user rights and access to justice.

\section{Copyright Users and Remedies}

Copyright users have limited remedies against copyright holders when they are constrained (either by contract or TPM) in legitimate uses that they want to make of a copyright work. The CCA provides extensive remedies to copyright holders against copyright infringers but says nothing about recourses that may be available to copyright users who are constrained in their uses of copyright works. Other jurisdictions including France, the UK and Belgium, have introduced mechanisms

17 See CCH Canadian Ltd. v Law Society of Upper Canada (1999), [2000] 2 FC 451 (TD): the defendant Law Society of upper Canada unsuccessful counterclaim for a declaration of non-infringement of copyright; cross appeal dismissed on appeal: CCH Canadian Ltd. $v$ Law Society of Upper Canada, 2002 FCA 187; cross-appeal dismissed by the Supreme Court of Canada: $\mathrm{CCH}$, supra note 1.

18 Canadian Copyright Licensing Agency v. York University, 2017 FC 669, para 2 (notice of appeal filed by York University, September 22, 2017).

19 A good example is the doctrine of classification of terms in the common law of contracts whereby different categories of breaches of contract will impact the nature of the remedies that will be available. See Hong Kong Fir Shipping Co. Ltd. $v$ Kawasaki Kisen Kaisha Ltd., [1962] 2 QB 29, [1962] 1 All ER 474.

20 Conceptions of "access to justice" are discussed below in Part 3.1."Access to justice sphere of inquiries". 
that mediate access to copyright works between users and copyright holders imposing an obligation to copyright holders to grant access to copyright works to users in certain cases. ${ }^{21}$ For instance, such mechanisms are available to users who want to perform legitimate acts (e.g., benefit from an exception to copyright infringement) but are precluded from doing so because the copyright work is protected by a TPM. ${ }^{22}$ Another scenario involves granting access to users to certain aspects of the copyright work for interoperability purposes. ${ }^{23}$ EU Directive 2001/29/EC ${ }^{24}$ imposes an obligation on its Member States to require copyright holders to make available to beneficiaries of certain exceptions to copyright the means by which to benefit from those exceptions. ${ }^{25}$ While the benefit and efficiency of these mechanisms may be difficult to assess, ${ }^{26}$ they come closest to a defined recourse for copyright users against copyright holders restraining legitimate uses of their works.

The Marrakesh Treaty to Facilitate Access to Published Works for Persons Who Are Blind, Visually Impaired, or Otherwise Print Disabled, ${ }^{27}$ is the first multilateral instrument that centres on the interests of a defined class of copyright users. The Treaty requires Member States to ensure that TPMs implemented in their jurisdiction do not prevent beneficiaries from enjoying the exceptions to copyright infringement set out in the treaty. ${ }^{28}$ Depending on how this obligation is implemented by the Member States of the Treaty, it may give rise to the basis of a claim for beneficiaries who are prevented to make uses of copyright works allowed under the Treaty. ${ }^{29}$

Absent specific mechanisms in place, the odds are stacked against copyright users when it comes to making a successful claim against copyright holders who constrain the legitimate use of a copyright work. The main reason is that the essence of the copyright grant under the CCA and other similar laws is to confer broad discretion in how right holders exploit their works with a priori no duty to account to anyone about how they decide to do so. That is at its base what property rights confer, ${ }^{30}$ and copyright, as uniquely distinct as it may be, does share several attributes common to other property interests. ${ }^{31}$

21 France CPI, supra note 5, art L 331-7, L 331-31; Belgium Wetboek van economisch recht/Code de droit économique, art XI $291 \S 2$. See also UKCDPA, supra note 9, ss 296ZE and 296ZEA (the regulations that added s. 296ZEA were quashed prospectively: $R$ (on the application of British Academy of Songwriters, Composers and Authors Musicians' Union E Ors) $v$ Secretary of State for Business, Innovation and Skills E Anor [2015] EWHC 2041 (Admin)).

22 Ibid.

23 See e.g., France CPI, supra note 5, art L 331-5, L 331-31-32.

24 EC, Parliament and Council Directive 2001/29/EC of 22 May 2001 on the harmonisation of certain aspects of copyright and related rights in the information society, [2001] OJ, L 167/10.

25 Ibid, art 6(4).

26 For instance, some of the recourses available to copyright users involve a mediation phase between copyright users and copyright holders which may be successful but which is not documented: see e.g., UKCDPA, supra note 9, ss. 296ZE and 296ZEA (the regulations that added s. 296ZEA were quashed prosectively: $R$ (on the application of British Academy of Songwriters, Composers and Authors Musicians' Union $\mathcal{E}$ Ors) v Secretary of State for Business, Innovation and Skills $\mathcal{E}$ Anor [2015] EWHC 2041 (Admin).

2727 June 2013, (entry into force 30 September 2016) online: <http:/ / www.wipo.int/treaties/en/text.jsp?file_id=301016> accessed 22 June 2018. As of that date there were 39 parties to the treaty.

28 Ibid, art 7

29 See e.g., CCA, supra note 2, s 32.01 (1) (implementing Canada's obligations under the Treaty (supra note 27) and creating a privilege in favour of defined non-profit organizations to perform certain acts without the permission of copyright holders, while not imposing positive obligations on copyright holders to grant access to certain works for persons with a "print disability" (as defined)); Directive (EU) 2017/1564 of 13 September 2017 on certain permitted uses of certain works and other subject matter protected by copyright and related rights for the benefit of persons who are blind, visually impaired or otherwise print-disabled and amending Directive 2001/29/EC on the harmonisation of certain aspects of copyright and related rights in the information society, [2017] OJ, L 242/6 (implementing EU obligations under the Treaty by establishing a mandatory and harmonized exception to copyright infringement covered by the Treaty. The Directive applies the regime of positive obligations that may be imposed on right holders using TPMs to grant access to their copyright works as set out in Directive 2001/29/EC, supra note 24 , art 6(4)).

30 Harris (1996, pp. 5, 65), referring to "self-seekingness" as one of the key attributes of ownership of property, i.e., this intimate relationship between the owner and the resource as to how they choose to dispose of the resource, with prima facie no duty to account to any one for the merit or rationality of that preference.

31 Courts often refer to copyright as property. In Canada, see e.g., Desputeaux v. Éditions Chouette, [1987] 2003 S.C.C. 17, para. 57 ; Euro-Excellence Inc. v. Kraft Canada Inc., [2007] S.C.C. 37, pp. 27-39; BMG Canada v. John Doe, [2005] F.C.A. 193, para. 41; Cie Générale des établissements Michelin v. C.A.W. Canada, [1996] 71 C.P.R. 3d, 348. See also Chapdelaine (2014); Howe and Griffith (2013), which contains several chapters focusing on the property attributes of copyright. 
Many features of copyright law help explain the lack of user remedies discussed in this article. First, the copyright holder centric design of copyright has led among others, to undermining the personal property users have to commercial copies of copyright works, to the point of near insignificance in the case of digital copies (Perzanowski and Schultz 2016; Chapdelaine 2017, pp. 19-27). Second, it is not clear at all that exceptions to copyright infringement confer rights in the sense that they create a positive duty of right holders to allow users to benefit from such exceptions (Chapdelaine 2017, pp. 49-52). From this it follows that claims against copyright holders to obtain access to restricted legitimate uses do not at present rest on solid grounds. Third, even if we admit that copyright holders would have a duty to copyright users, it is not clear at all that exceptions to copyright infringement are mandatory or that they cannot be set aside by contract (Chapdelaine 2017, pp. 52-54). Again, the premise would be that exceptions to copyright infringement set a default rule and that copyright holders should be free to contract out of that rule on the assumption that they are better positioned to decide the conditions under which they make their works available. I intentionally leave out the user "agreeing" to contract out of exceptions to copyright infringement as a very large portion of copyright works are commercialized through non-negotiated standard form agreements where the user is generally not aware of what they are giving up. ${ }^{32}$ To the extent that exceptions to copyright infringement may indeed be set aside by contract, whatever benefit a user may have under copyright law may be set aside by contract or through the application of a TPM to protect the work, leaving the user who has "agreed" to such terms with no claims (Chapdelaine 2013, pp. 35-37).

Given copyright law's shortcomings to address the rights and remedies of copyright users, many have argued that other bodies of law are well equipped to address users' potential grievances against copyright holders. ${ }^{33}$ In previous work that analysed how copyright users could make successful claims against restricted uses of copyright works based on breach of contract, sale of goods or consumer law, breach of duty of good faith or tort, I concluded that such bodies of law are ill equipped to address users' legitimate claims against copyright holders (Chapdelaine 2017, pp. 62-85). Contract terms (or in absence of contract terms, TPMs) that block the exercise of exceptions to copyright infringement or that provide restrictions on materials not protected by copyright would hardly constitute a breach of implied warranty of quality, fitness for purpose or of quiet possession, under the relevant consumer law or sale of goods law (Chapdelaine 2017, pp. 62-85). Copyright users who are constrained in legitimate uses of copyright works such as benefiting from an exception to copyright infringement (i.e., reproduce a computer program for back up purposes or create a new work using an underlying work for non-commercial purposes such as by creating a video for YouTube) will find little solace in other bodies of law including contract law, or based on breach of implied obligations (quality, fitness for purpose, quiet possession) under sale of goods or consumer law (Chapdelaine 2017, pp. 62-85). ${ }^{34}$ The success of claims that restrictive terms of use or TPMs amount to unfair commercial practices is at best uncertain (Chapdelaine 2017, pp. 62-85). ${ }^{35}$ The endorsement in Canada and elsewhere of TPMs, the uncertain status of exceptions to copyright infringement as rights or privileges and as to whether they may be contracted out, and the weak personal property rights of users in copies of works

32 Chapdelaine (2013, pp. 26-28), (examining a sample of standard terms of use of commercial copies of copyright work). In jurisdictions where the relevant copyright statute is silent on the effect of such contract terms on exceptions to copyright infringement, they may be valid (see above Part 1. "Introduction: the uncertain contours of copyright user rights" on the different interpretations of the statutory silence on the enforceability of such contract terms).

33 See e.g., Australia Commonwealth (2013, pp. 435-58), (on the discussion on the appropriateness of making exceptions to copyright infringement mandatory, pointing to other legal doctrines, such as the doctrine of public policy in contract law, consumer protection law, the doctrine of copyright misuse, that could ensure that the rights of users are adequately protected).

34 See below in this section.

35 See also Perzanowski and Schultz (2016, pp. 87-97), on possible arguments of false and misleading advertising claims (in a US context) against copyright holders representing to consumers that they are selling copies of copyright works while the terms of the contract have another effect. 
they own, explain in part the difficulty of making successful claims against restrictive uses based on contract, sale of goods or consumer law. These contributing factors are in addition to broader systemic obstacles encountered by consumers to assert legal claims. ${ }^{36}$

In other instances, users may have a claim against copyright holders whose restricted access to copyright works amounts to an anti-competitive practice but even there, Canadian competition law leans toward granting intellectual property holders a fair amount of deference and discretion in how they exploit and commercialize their copyright work (Canada Competition Bureau 2016; Pecman 2016). Even in other jurisdictions with developed doctrines on the abuse of intellectual property rights at the expense of consumers and the public, such as the doctrine of copyright misuse in the United States, the threshold for a finding of abuse or misuse is fairly high, with the result that such doctrines are quite limited in their application. ${ }^{37}$

There is little that formal law and remedies can do for copyright users. Not only must copyright users look outside copyright law, they currently need to look outside the law. Users who get access to works that are blocked by copyright holders may have to do so outside the boundaries of the law.

Given the uncertain nature of exceptions to copyright infringement as privileges or rights, and the limited scope of user property rights in copies of copyright works, the question becomes whether mourning over the lack of remedies for copyright users and advocating for more would do much at this point to improve the status of copyright users and their access to copyright works.

\section{Copyright Users and Access to Justice}

\subsection{Access to Justice Sphere of Inquiries}

It is beyond the scope of this article to provide an extensive review of the literature on access to justice. I will refer to the five predominant "waves" of thought about access to justice as identified and summarized by Roderick A. Macdonald from a Canadian perspective (Macdonald 2005), as a framework of analysis of the various questions that an access to justice enquiry may trigger with respect to copyright user rights.

Macdonald identified the first wave of access to justice thinking and literature, spanning roughly through the 1960s, as focusing on access to lawyers and courts (Macdonald 2005, p. 20). The main focus of attention revolved around issues of cost, delay, and complexity in the legal system for economically disadvantaged groups. Legal aid programs were perceived as being the main panacea to resolve those issues (Macdonald 2005, p. 20). The second wave of access to justice focused on institutional redesign. It spun throughout the seventies, and broadened the scope of analysis to actual performance of courts, their procedure and organization. This led to proposals to create small claims courts, allow class actions, and allow contingency fees, among others, to increase availability of redress (Macdonald 2005, pp. 20-21). At the government level, preoccupations of access to redress led to setting up regimes such as no-fault automobile compensation or workers' compensation appeals (Macdonald 2005, pp. 20-21). The third wave of access to justice that developed in the 1980s, called "demystification of law", focused on problems of equality, both in the capacity and opportunity to litigate, and on the outcomes (Macdonald 2005, p. 21). Contextualizing access to justice by reflecting on systematic processes and frameworks that perpetrate inequalities among various (minority) groups within society, or by looking at societal norms that may impede taking action to correct a wrong expands the spheres of inquiry and at the same time offers a better chance of addressing root causes of injustice beyond access to

36 There are important obstacles to the enforcement to consumer claims that include prohibitive legal fees, low monetary value of individual claims, limited access to class actions or other collective defense of consumer interests. For an overview of the different theories and strategies employed for the regulation of consumer protection and enforcement issues, see, Cafaggi and Micklitz (2009), in particular Samuel Issacharoff \& Ian J. Samuel, “The Institutional Dimension of Consumer protection" pp. 47-62.

37 On the application of the doctrine of copyright misuse in the US to copyright holders' commercial practices, see Cobb (2014, p. 545ff). On the possible application of the abus de droit doctrine in Québec civil law, see Moyse (2008). 
courts. ${ }^{38}$ This wave of access to justice includes legal reform at the substantive level (e.g., family property law, child welfare) and processes of criminal sentencing (e.g., young offenders legislation) and greater attention to restorative justice (Macdonald 2005, pp. 21-22). The wave of demystifying law also encompassed the plain language movement and tools such as mandatory standard-form consumer contracts (Macdonald 2005, p. 22). The fourth wave of access to justice spun throughout the 1990s and focused on preventative law as a recognition that real access to justice had to encompass multiple means of non-dispute-resolution or ADR (Macdonald 2005, p. 22). Recent developments of online dispute resolution platforms either in the private sector (e.g., e-Bay) or in the public sector would fall into the type of initiatives that preoccupies the fourth wave of access to justice. ${ }^{39}$ The fourth wave also saw a need to improve processes to involve the public in law-making bodies (parliamentary committees, rule-making hearings of administrative bodies). The fourth wave on conceptions of access to justice also became preoccupied with law-making by non-public bodies (e.g., private standards organizations or by-laws promulgated by owners of shopping centres, or other land owners) (Macdonald 2005, p. 22). The fifth wave: "proactive access to justice", spanning throughout the 2000s and onward, recognizes that access to justice issues concern every aspect of the social life of citizens (Macdonald 2005, p. 23). This translates into providing equal opportunities to gain full access to positions of authority within the legal system (Macdonald 2005, p. 23).

Breaking access to justice into its components, "access" evokes approaching, entering, and accessibility includes the ability to influence (Ghai and Cottrell 2010, p. 3). "Justice" comprises fairness, and in the legal and political sphere, it typically means the "exercise of authority and maintenance of rights (Ghai and Cottrell 2010, p. 3)." Fairness encompasses procedures, access and the substantive rules that define the exercise of authority (Ghai and Cottrell 2010, p. 3). ${ }^{40}$ A broader view toward improving access to justice beyond access to courts looks at "formal and informal justice mechanisms and improving the justice quality of daily life" (Australia Attorney General Department 2009, p. 4).

The five waves of scholarly work and public initiatives summarized above indicate how issues of access to justice became increasingly viewed as extending beyond access to lawyers and courts (Australia Attorney General Department 2009, p. 4). Each successive wave on how scholars and various interest groups perceived access to justice did not supersede the other; rather each wave dug deeper into the multi-layered complexities of access to justice. Far gone are the days where a lack of access to justice meant not being able to bring one's case in court. An access to justice inquiry extends to issues such as what rules, how and by whom those rules are made and their impact on an individual or chosen group (Australia Attorney General Department 2009, p. 4).

Based on the particularities of copyright, on the shortcomings of the treatment of copyright users in copyright law, and their limited remedies described above, we may have much to gain from the insights derived from the different waves and currents on how to think about access to justice. Particularly, the insights of the third and fourth wave of access to justice respectively inform us about the greater gains to be made by focusing on the substantive law and on issues of equality, and on addressing particular issues (e.g., and for our purposes: copyright users access to copyright works) preventively rather than through the traditional channels of adversarial procedures. Those procedures have and likely will continue to have little to offer to copyright users, at least, the more vulnerable groups of users ${ }^{41}$ so long as we fail to fix the fundamental structural inequalities that subsist within

38 On the broader contextualization of the issues involved in access to justice, see Backhouse (2005). On how societal norms influence decisions to have wrong corrected and to take legal action, see Engle (1984).

39 See e.g., Rabinovich-Einy and Katsh (2017a) (on the potential and perils of online dispute resolution as potentially increasing efficiency and fairness of dispute resolutions, while pointing to the dangers of online dispute resolution mechanisms possible biases and lack of fairness due to their reliance on algorithms); Katsh and Rabinovich-Einy (2017) (examining how new technologies and social media generate new disputes while at the same time offering opportunities of resolving and preventing disputes).

40 For a brief overview of different meanings of access to justice, see: Akin Ojelabi (2010, pp. 10-13).

41 See below Part 3.3 ii "Attention to specific classes of users". 
copyright law and between the rights of copyright holders and of users. ${ }^{42}$ We certainly have much to gain from the fifth wave of access to justice that views the involvement and representativeness of the marginalized, neglected members of certain groups or classes at every stage of law making processes as central to improving access to justice for that particular group.

I will apply these distinct waves of thinking about how to improve access to justice for copyright users in the next Part 3.3 of this article. Before doing so, one needs to ask: what does access to justice mean in the context of copyright law more generally and its main interested parties?

\subsection{Access to Justice for Authors and Copyright Holders}

Looking at how we may achieve greater access to justice for copyright users may leave some to wonder: what about authors and copyright holders? Are authors not the first ones we think about when pondering about the effects of the digital age and how the large scale copying and access to their works eat away their means of sustenance? Or about some renowned artist misappropriating an unknown author's creation, the fruit of their labour? After all, there would be no users of books, music, photos, news articles, and films without their authors. Discussing concepts of justice for copyright users without also discussing conceptions of justice for the authors of the creations to which users want access may depict an incomplete view, leaving out the main parties concerned, the authors and copyright holders without which there would be no need to discuss copyright user rights in the first place.

An access to justice standpoint invites us to focus on the disenfranchised, at the groups neglected by official laws and power. While much can be said about the value of promoting and protecting the rights of creators and their producers, this is precisely what official laws and norms at the national and international levels have been promulgating and implementing for decades, by progressively increasing the powers of right holders in duration, scope and subject matter. ${ }^{43}$ Not the least of which the protection of an author's "material and moral interests" in their "scientific, literary or artistic production" is enshrined by the Universal Declaration of Human Rights. ${ }^{4}$

Admittedly, these international and national copyright regimes and norms may not have been as successful at protecting the interests of individual authors, or with respect to certain groups (e.g., indigenous peoples and their traditional cultural expressions) as they have been with large copyright holder entities (e.g., music label companies, film producers, software distributors, publishers). ${ }^{45}$ With respect to individual creators, initiatives such as the proposed US bill The Copyright Alternatives in Small-Claims Enforcement (CASE) Act of 2017,46 is one attempt to address the particular needs of individual authors, and falls under the second wave of solutions envisaged to improve access to justice (Macdonald 2005, pp. 20-21). ${ }^{47}$ Some parallels may even be drawn between the copyright regime's inability to adequately protect the interests of authors on the one hand, and of copyright users on the other.

An access to justice outlook that pays more attention to copyright users joins the choir of the many voices that have critiqued intellectual property and copyright laws' increasing levels of protection

42 See above Part 2 "Copyright users and remedies", and below Part 3.3 (i) "Justice for users".

43 Various multilateral treaties have progressively increased the level of protection of copyright worldwide: Berne Convention for the Protection of Literary and Artistic Works, 9 September 1886, 828 UNTS 221, and subsequent revisions; Agreement on Trade-Related Aspects of Intellectual Property Rights, Marrakesh Agreement Establishing the World Trade Organization, Annex 1C, 15 April 1994, 1869 UNTS 29, 33 ILM 1197 [TRIPS]; WIPO Copyright Treaty, 20 December 1996, WO033EN; WIPO Performances and Phonograms Treaty, 20 December 1996, WO034EN. Canada has followed suit, with copyright protection progressively increasing in duration, scope, and subject matter over the last century.

44 UN General Assembly, Universal Declaration of Human Rights, 10 December 1948, 217 A (III), art 27.

45 See D'Agostino (2010) for a discussion on the protection of freelance authors in copyright law, and in particular, with respect to the misalignments between the interests of authors and copyright holders, and how the rights and interests of authors can be better protected, ibid, pp. 201-89.

46 H.R. 3945.

47 For a critique of the proposed Bill, see Samuelson and Hashimoto (2017). 
for having lost sight of the public interest and wanting justification. ${ }^{48}$ Le temps est venu de remettre les pendules à l'heure. ${ }^{49}$

Exploring how we may increase access to justice for copyright users is not about disregarding the rights of authors and copyright holders. It involves a reallocation of privileges and powers among these groups that is arguably more aligned to copyright's core declared instrumental objective to incent the creation and dissemination of works, ${ }^{50}$ or in a US context, to "promote the progress of science and useful arts." ${ }^{\prime 51}$ It critically assesses how copyright law, similarly to other intellectual property protection regimes, may become counterproductive to its initially stated goals of incenting creations and the dissemination of works. ${ }^{52}$ This reallocation of powers and privileges among right holders and users could be achieved through various reforms as further explored in this article. ${ }^{53}$ Within the proposed reforms, the outer limits to asserting greater rights and privileges to access copyright works should take into account the effect that these augmented user rights and privileges would have on the economic rights of copyright holders and moral rights of authors. ${ }^{54}$

The intrinsic nature and exigencies of the creative process are such that authors and copyright holders are at any given point in time users of someone else's works; more generally, copyright users are an integral part of that process (Cohen 2005, pp. 370, 373)..$^{55}$ To view authors, copyright holders on the one hand and users on the other as two distinct monolithic groups loses sight of this ineluctable reality. As the law still makes a sharp distinction between right holders and users, a reallocation of powers and privileges that takes into account the legitimate interests of copyright users, and the extent to which they serve the purpose of copyright is not a zero sum game where the users' gains would necessarily be the right holders' loss. As the creative process itself dictates, authors and right holders alike would gain from a recalibration of the powers and privileges between copyright holders and users.

\subsection{Access to Justice and Copyright Users}

Looking at the access to justice issues that may confront copyright users more specifically within the broader regime of copyright invites us to define (or at least attempt to define) what we mean by "justice" for copyright users. Second it requires a consideration of whether certain categories of users are more vulnerable or marginalized than others. Third, justice for users also involves critically evaluating what giving more remedies (i.e., in the traditional sense of orders granted by a court of law) to copyright users would achieve to make user rights more just. Fourth, what types of reform might be helpful to make the position of copyright users more just? I will explore each of these access to justice considerations as they relate to copyright users.

\section{(i) "Justice" for copyright users}

48 See e.g., Drahos and Braithwaite (2002); Heller (2010).

49 i.e., to set the record straight, here about the state of copyright law and the scope of user rights.

50 The Statute of Anne, 8 Ann c. 19 (1710) (An Act for the Encouragement of Learning, by Vesting the Copies of Printed Books in the Authors or Purchasers of such Copies, during the Times therein mentioned), the first codification of copyright in a common law jurisdiction regulated by the State, embodies instrumental objectives of copyright geared toward the public interest. In a Canadian context, the leading judgment by the Supreme Court stating the objectives of copyright is Théberge, supra note 4 at para 30.

51 US Constitution, art 1 s 8 (conferring to Congress the power "To promote the Progress of Science and useful Arts, by securing for limited Times to Authors and Inventors the exclusive Right to their respective Writings and Discoveries").

52 See Heller, supra note 48 (generally on the overprotection of intellectual property leading to the tragedy of the anti-commons').

53 See below Part 3.3 (iv) "What reforms for copyright users?".

54 Ibid.

55 Referring to the "situated user", i.e., one "who appropriates cultural goods found within her immediate environment for four primary purposes: consumption, communication, self-development, and creative play. The cumulative result of this behaviour by situated users, and of both planned and fortuitous interactions among them, produces what the copyright system names, and values, as "progress.", as being as important to the engine of progress as the incentive to authors to create." 
There is growing recognition that advocating for the advancement of the rights of users is equally important as incenting and rewarding authors to attain the broader ideals and objectives of copyright law. ${ }^{56}$ The purpose here is not to provide a definitive answer on what justice should mean for copyright users. The endeavour is a more modest one that focuses on core objectives that should be pursued when thinking about what more "just" copyright user rights would look like, and to propose themes around which further research and legal reform should gravitate.

First, justice for copyright users requires looking at the level of access that users should have to copyright works in a democratic society, and at the barriers, within and outside copyright law that go against allowing such access. ${ }^{57}$ What optimal levels of access to knowledge (or "A2K"), creations and innovations should we enable for users and under what rules and conditions (including having due regard to the rights and interests of copyright holders)? The question of optimal access to knowledge goes above and beyond what copyright regulation alone can enable and bear: issues of access to adequate education, and the various means, public and private through which copyright works are available have significant bearing on access to knowledge. At the same time, at least in Canada, the objectives of copyright law as stated by our Supreme Court in Théberge require having due regard to the extent to which copyright law should facilitate access for users:

The Copyright Act is usually presented as a balance between promoting the public interest in the encouragement and dissemination of works of the arts and intellect and obtaining a just reward for the creator $[\ldots] .58$

Those copyright objectives should guide how we interpret and consider reform in the area of the rights conferred on copyright holders through among others, the technological protection measure regimes in Canada and elsewhere. ${ }^{59}$

The multi-layered complexity of how to best ensure adequate access to knowledge is no reason to diminish the role copyright law and policy can play toward achieving that goal. At the international level, the interaction between copyright law and policy and access to knowledge is part of the broader conversation of how intellectual property may enable development. ${ }^{60}$ There, questions of access to knowledge and development are raised against an international regime that has traditionally almost exclusively focused on advancing the merits of copyright holder exclusive rights (Kapczynski 2008, pp. 821-39). ${ }^{61}$ As Ruth Okediji points out:

[t]he negotiations during each iteration of the Berne Convention framed the meaning of "rights" as if the only rights at issue were the copyright owner's rights of exclusion, forgetting that the public has rights that also matter a great deal, such as rights to read the books, to watch the movies, and to access the underlying ideas expressed in any copyrighted work. (Okediji 2017, p. 443) ${ }^{62}$

56 See e.g., Elkin-Koren (2016, p. 36).

57 For the history of the development of the access to knowledge movement within international copyright law (through key ideas and concepts, specific interest groups, and international institutions) see Bannerman (2016); Kapczynski (2008) (on the historical development of A2K as a counter movement and response to the progressive evolution of intellectual property enclosure). See also Thompson (2007); Al-Sharieh (2018, pp. 22-23), (arguing that current international human rights law's attention to authors' rights over their intellectual creations, along the rights of users to access and share authors' works, is an attempt to maintain a "just order in the ecosystem of knowledge creation, use, and distribution").

58 Théberge, supra note 4 at para 30.

59 For a critique of technological protection measures blocking out lawful uses or on possible regimes of implementation that would leave lawful uses of works unencumbered see Geist (2010), in particular ch 7: Carys Craig, 'Locking Out Lawful Users: Fair Dealing and Anti- Circumvention in Bill C- 32' and ch 8: Michael Geist, 'The Case for Flexibility in Implementing the WIPO Internet Treaties: An Examination of the Anti-Circumvention Requirements.'; see Electronic Frontier Foundation (2014).

60 See World Intellectual Property Organization (2018) (on the decision of the General Assembly in 2007 to endorse a development agenda and to establish a Committee on Development and Intellectual Property); Okediji (2017).

61 On the historical development of A2K as a counter movement and response to the progressive evolution of intellectual property enclosure.

62 Founding the rights of the public on existing liberty rights to reproduce or use authorial works as necessary. 
The prevailing discourse in international forums that more intellectual property protection would necessarily promote economic development has led to many assumptions being made without much substantiation or scrutiny (Okediji 2017, p. 436) ${ }^{63}$ This discourse has tended to downplay how leading industrialized countries have benefited in the past from lower (or no) levels of copyright protection for their own economic development (Okediji 2017, p. 438). A more flexible approach that is attuned to the socio-economic and cultural reality and needs of a particular nation or region is likely to achieve more positive outcomes toward A2K and development than "one-size-fits-all" assumptions about the role of intellectual property in promoting economic and social growth (Okediji 2017, p. 483). ${ }^{64}$ This entails a more concerted strategy at the international level that pays greater attention to the users, readers, innovators, and other recipients of copyright works rather than focusing on authors and copyright holders.

There is movement toward a greater recognition of the rights and interests of users within international copyright law and policy. The Marrakesh Treaty to Facilitate Access to Published Works for Persons Who Are Blind, Visually Impaired, or Otherwise Print Disabled, ${ }^{65}$ is the first multilateral instrument that centres on the interests of a defined class of copyright users. The World Intellectual Property Organization (WIPO) is spear heading an initiative for the introduction of an international legal instrument on exceptions and limitations for libraries and archives (WIPO 2013). Much more remains to be done toward a coherent articulation of how copyright law and policy may enable and support $\mathrm{A} 2 \mathrm{~K}$ and development. The redesign of international copyright limitations and exceptions and in particular, the need for the harmonization of an education exception to copyright infringement comes to mind as one important step in that direction (Okediji 2017, pp. 483,484-87).

Second, more justice for copyright users means respect for users' fundamental rights. A significant body of literature looks at intellectual property and copyright law from the perspective of human rights. ${ }^{66}$ By protecting the rights of authors and copyright holders to their literary, dramatic, musical and artistic works, copyright law may be viewed as a conduit that facilitates the freedom of expression of authors and copyright holders, as protected under the Canadian Charter of Rights and Freedoms [Canadian Charter] ${ }^{67}$ The idea vs. expression dichotomy ${ }^{68}$ is one feature of copyright law that is invoked to support the view that copyright law does not impede on freedom of expression. ${ }^{69}$ In that view, copyright law protects the original expression present in works, not the underlying ideas embedded in the work, leaving others free to express similar ideas by creating their own works. Because copyright protects original expressions without regard to their novelty, two identical works could each deserve copyright protection if they originate independently from each author (without one having copied or been in contact with the work of the other) ${ }^{70}$ In that scenario, each author's own expression is equally entitled to copyright protection and unimpaired by the independent expression of the other. ${ }^{71}$

63 Noting the lack of scrutiny of claims and assumptions that more copyright protection encourages development.

64 Arguing that if copyright law is to play a role in economic growth, then it should look different in developing countries, and that international copyright law, as a social institution, should enable this difference.

65 Supra note 27.

66 See e.g., Reynolds (2016); Izyumenko (2016); Tawfik (2015); Human Rights Council, Report of the Special Rapporteur in the field of cultural rights, Farida Shaheed -Copyright policy and the right to science and culture, UNGAOR, 28th Sess, Agenda Item 3 , UN Doc A/HRC/28/57 (2014); Netanel (2013); Hugenholtz (2001); Cohen (Cohen 1997, p. 1014ff).

67 Canadian Charter of Rights and Freedoms. Part I of the Constitution Act, 1982, being Schedule B to the Canada Act 1982 (UK), 1982, c11.

68 Copyright protects the expression of ideas, not the ideas themselves: TRIPS, supra note 43, article 9(2).

69 See e.g., Reynolds (2016, p. 929), (referring to this frequently invoked argument that copyright law does not protect ideas and information, while acknowledging that the distinction between what constitutes an idea and what constitutes expression of that idea is sometimes hard to make).

70 Feist Publications, Inc. c. Rural Tel. Service Co., 499 U.S. 340 (1991), 345-46; CCH, supra note 1, para 25 (stating the test for originality in Canadian Copyright law: the work must not be copied from another work and must be the product of author's exercise of skill and judgement).

71 Ibid. 
In reality, the exclusive rights conferred on copyright holders and their interpretation by courts make the line between idea and expression blurrier. The exclusive right to produce or reproduce a work in any material form ${ }^{72}$ the possibility that a work may be infringing another beyond literal copying, through the finding that substantial "expressive elements" of the original work found their way in the infringing work, ${ }^{73}$ and the monopoly conferred on right holders to restrict the translation, adaptation or conversion of their literary works into dramatic works, ${ }^{74}$ all these facets of copyright illustrate how when one user or author accesses the work of another author, the exclusive rights of this latter author may extend over and above their original expression and get closer to the underlying ideas and concepts that withstand this author's expression. As such, original expressions of myriad art forms may be to some extent barred by copyright law on the basis that they infringe pre-existing protected works.

Exceptions to copyright infringement are also invoked as one feature of copyright law that preserves the freedom of expression of users of copyright works and the public. ${ }^{75}$ In particular, fair dealing for the purpose of criticism and review, or parody and satire, safeguards the value of freedom of expression by allowing someone to use a protected work without the permission of the copyright holder, to express their own views about the protected work, provided that the dealing is fair. ${ }^{76}$ However, unless one of the exceptions to copyright infringement applies, by conferring exclusive rights over expressive works, copyright law may still restrain the expression of others to the extent that they may want or need to use protected copyright works (or substantial parts thereof) as an integral part of their own expression, reuses which are in many ways intrinsically linked to the creative process. ${ }^{77}$ In addition, there may be concerns that copyright holders could seek to enforce their exclusive rights to silence criticism of the state, private entities and other institutions, by prohibiting the uses of copyright works that may be necessary to express a specific message. ${ }^{78}$

The conformity of the CCA to the Canadian Charter has been an under explored area of the law compared to other jurisdictions; only one judgment by the Federal Court of the late nineties Compagnie Générale des Etablissements Michelin v. National Automobile, Aerospace, Transportation and General Workers Union of Canada (CAW-Canada $)^{79}$ offers an exhaustive review of the interaction between copyright law and the Canadian Charter (Reynolds 2017). An increasing body of scholarship is looking into the application of the Canadian Charter to the CCA, acknowledging the continuous evolution of these two important bodies of law, and calling for a more thorough investigation of the constitutionality of the $C C A .^{80}$

While the CCA may encourage the freedom of expression of right holders and to some extent, users of copyright works, the conformity of the CCA to the Canadian Charter should not be taken at face value ${ }^{81}$. The impact copyright has on users and the public domain should remain under the strict scrutiny of Canadian Charter analysis at the stage of evaluating forms of user expressions that are

72 CCA, supra note 2, s 3(1).

73 See Cinar Corporation v. Robinson, 2013 SCC 73 paras 31-32 (adopting a holistic and qualitative approach to whether a substantial part of a work was taken rather than a piecemeal one to the copied features).

74 CCA, supra note 2 , s 3(1).

75 See scholarship looking at the interaction between copyright and freedom of expression, supra note 66.

76 CCA, supra note 2, ss 29-29.2; CCH, supra note 1 at paras 48-73.

77 One example that comes to mind is "appropriation art" which may not constitute a fair dealing in Canada, while it has been considered fair use in the US: see Cariou v Prince, 714 F (3d) 694 (2d Cir 2013).

78 See e.g., Scassa (2002, p. 962); Reynolds (2016, pp. 30-33).

79 [1997] 2 R.C. 306 (F.C.), the Federal Court holding that the restrictions imposed by the CCA on the use of copyright works did not contravene to the Canadian Charter.

80 See Reynolds (2017) (including pp. 33-34, for a review of the scholarship on the compliance of the CCA to the Canadian Charter guarding against preconceived assumptions that the application of the CCA is compliant with the Charter and that any limitation of protected expressions is compliant with restrictions permitted under Canadian Charter s. 1).

81 (Tawfik 2015, p. 278); (Reynolds 2016, pp. 29-35); (Al-Sharieh 2018, p. 31) (arguing that assumptions being made about Parliaments having already weighed in freedom of expression in the allocation of exclusive rights of copyright and exceptions thereto "excuses courts from identifying instances, not envisaged by statutory copyright exceptions, where copyright may encroach upon freedom of expression"). 
protected and if they are, whether their restriction by copyright law is justified under Section 1 of the Canadian Charter. ${ }^{82}$ The recent evolution of a more user-regarding approach to copyright law requires that we revisit the extent to which the exclusive rights conferred on copyright holders play out at each phase of the Charter analysis (Reynolds 2016, pp. 36-39). ${ }^{83}$

Given the stated purpose of the CCA, as declared by the Supreme Court in Théberge to act "as a balance between promoting the public interest in the encouragement and dissemination of works of the arts and intellect and obtaining a just reward for the creator ${ }^{\prime \prime 4}$ the CCA should act as a conduit that enables the freedom of expression of users just as it does for authors and copyright holders. A presumption of equality between the freedom of expression of authors, copyright holders and users should apply when mediating between the exclusive rights of copyright holders on their works and their use by the public. Just as concepts of autonomy and human dignity may to some extent justify granting copyright protection to authors as per the Universal Declaration of Human Rights, ${ }^{85}$ (in particular as it concerns the moral rights of authors), due regard should be had to the autonomy and dignity of copyright users which may need to rely on the author's work as a conduit to a specific form of expression (Drassinower 2015, p. 179). ${ }^{86}$ Any restraint on the freedom of expression of copyright users based on the exclusive rights of copyright holders in the work should be viewed with suspicion as running counter to the underlying purpose of conferring copyright in the first place. Such restraints should come under a high level of scrutiny under Section 1 of the Canadian Charter. ${ }^{87}$

Last but not least, justice for copyright users demands that the personal property rights that they may have to copies of copyright works be recognized in their own right. The intangible nature of copyright has allowed it to insidiously take over in large part the property rights users have to copies of copyright works, making those property rights increasingly meaningless (Chapdelaine 2017, pp. 19-27; Perzanowski and Schultz 2016, pp. 57-101). Failure to fully account for the way in which the personal property of users in the copy of the work should act as a legitimate bar to the exclusive property rights of copyright holders in the work raises important questions on the application of equality between competing rights. This oversight results from the combination of several factors: successive copyright law reforms (e.g., with the introduction of technological protection measures to confer additional rights to copyright holders) through a confusion that subsists between goods and services in the context of digital products; through the failure to recognize digital copyright exhaustion; and in the way courts endorse copyright holder commercial practices (e.g., the practice to deprive users of full ownership rights by restricting their right to transfer the copy or other powers and privileges normally attached to ownership, when a sale took place at the substantive level) (Chapdelaine 2017, pp. 19-27; Perzanowski and Schultz 2016, pp. 57-101). Justice for users means nothing less than recognizing the place and rights that copyright users deserve consequential with the stated core objectives of copyright law.

\section{(ii) Attention to specific classes of users}

82 Canadian Charter, supra note 67, s. 1 provides that the rights and freedoms provided in the Canadian Charter are "subject only to such reasonable limits prescribed by law as can be demonstrably justified in a free and democratic society"; R. v. Oakes [1986] 1 SCR 103 paras 69-71 (setting the test that Canadian courts follow to determine whether a limitation to rights and freedoms under the Canadian Charter is justified. First, the objective must be "of sufficient importance to warrant overriding a constitutionally protected right or freedom", and second it must be shown "that the means chosen are reasonable and demonstrably justified" (proportionality assessment)); see Reynolds (2016, pp. 43-68).

83 On how we need to factor in that copyright law in Canada has shifted from an author-centric to a balancing of interests conception of copyright.

84 Théberge, supra note 4 at para 30.

85 Supra note 44 , article 27.

86 P ositing a copyright work as a communicative act which inherently sets limits to the author's rights such as with respect to transformative uses involving a user-defendant's own authorship, on the basis that the author-plaintiff's entitlement as a speaker should not bar the valid exercise of another's speech.

87 Supra note 67. 
Querying what issues of access to justice may be of particular concern for copyright users invites us to look at categories of users that may be more vulnerable than others. While the interests of Google, as a major user and aggregator of copyright works, and the ones of individual users may often be aligned, ${ }^{88}$ Google and individual users are obviously not in the same position when it comes to asserting or defending their rights. In some instances, Google and other large content and user-generated-content platforms have de facto power to regulate how copyright is enforced on those platforms, not necessarily to the benefit of individual users (Sag 2017).

At a more fundamental level, individual copyright consumers, from the seemingly passive to the more active "consumer-creators", share a vulnerability that needs to be of particular concern to the copyright law design and its underlying objectives. Niva Elkin-Koren argues in the context of copyright, that consumers of "cultural artefacts" may require even more attention than the consumer of mundane commodities:

Cultural artefacts are not simply useful commodities. While they often have an entertainment value that could be quantified, they also possess a communicative value and a symbolic significance. They engage our minds in a more direct and intimate way than do mundane commodities and, therefore, expose consumers to a higher risk of deeper and more intrusive restrictions of freedom. This particular vulnerability of information consumers is often overlooked. (Elkin-Koren 2007, pp. 1136-37)

From this perspective, individual copyright consumers and other users share vulnerabilities that are distinct from larger institutional copyright users and arguably even greater than consumers of other commodities.

Particular attention needs to be given to individual copyright users whether accessing copyright works through a commercial transaction or in the public sphere, on the basis of what their intimate relation with copyright works entails, and on the premise that knowledge of their rights and their ability to mobilize forces or to take legal action to enforce their rights are much more limited than for larger institutional users.

Social media, rating sites and various web platforms give disgruntled user-consumers unprecedented power that should not be underestimated when evaluating the broader context within which individual users access copyright works. Digital technologies empower individuals in the uses they can make of copyright works above and beyond what copyright law permits. These seemingly empowering tools do not eliminate individual user vulnerabilities. The ability for some users to do as they please regardless of what the law says is no indication that everything is well under the sun for users: the law and its endorsement of TPMs and copyright holders commercial practices impose important restrictions on copyright user legitimate privileges and powers. The disparity between what the law recognizes and protects on the one hand, and what some users do regardless, points to social norms that deviate from the law, and should be viewed as an important signal of the changes that may be required for a more just treatment of individual copyright users. ${ }^{89}$

\section{(iii) Limited value and function of traditional remedies for copyright users}

As summarized in Part 2 of this article, copyright users in Canada have no remedies under copyright law for allegedly illegitimate constraints in their uses of copyright works (e.g., constraints set by contracts or through TPMs) that would go against users' personal property rights in copies of copyright works, or bar users from the benefit of exceptions to copyright infringement. Contract

88 One example is how various user groups, large and small joined forces in early 2012 against the introduction of Stop Online Piracy Act US, Bill HR 3261, Stop Online Piracy Act, 112th Cong, 2011, and against the proposed Protect Intellectual Property Act US Bill S 968, Preventing Real Online Threats to Economic Creativity and Theft of Intellectual Property Act of 2011, 112th Cong, 2011. Both bills were subsequently abandoned.

89 See generally Penalver and Katyal (2010); see also Bebenek (2011) inviting market players and policy makers to pay greater attention to consumer preferences and the social norms that they reflect. 
doctrines, sale of goods and consumer law implied warranties and conditions are of little avail to copyright users. ${ }^{90}$ Claims that copyright holders' practices are anti-competitive need to meet fairly high thresholds and address specific market concerns. The absence of clear remedies for copyright users is reflective of the weak rights of copyright users both in the personal copies they own and pursuant to the exceptions to copyright infringement as they are set out in the $C C A .{ }^{91}$

In the best case scenario, i.e., where the rights of an individual or group are reasonably clearly laid out, an access to justice perspective reminds us that the existence of remedies available to rights that have been violated is a poor indicator on its own to determine whether justice is served for this group or individual. An access to justice approach to the nature and adequacy of copyright user rights brings under more scrutiny the merit of assessing user rights through the availability of remedies before a court of law or other adjudication body. Regardless of the strength of remedies in place, an access to justice perspective takes a broader approach that looks at the surrounding conditions under which remedies may be exercised. For instance, before a remedy is contemplated, looking at the phases of transformation of a dispute, leading to the articulation of a claim to seek compensation ("naming", "blaming" and "claiming") is often overlooked and yet is determinant of the chances one will ever get just reparation (Flestiner et al.).

In the case of copyright users, the weakness of the remedies available is a canary in the coalmine of the defects of copyright user rights. An access to justice perspective not only invites us to look outside tackling the poor remedies users have when constrained in legitimate uses they want to make of copyright works, it reinforces and validates the view that greater gains will be made by first addressing copyright user rights at the substantive level. This includes asserting the personal property rights users may have in copies of copyright works, clarifying whether exceptions to copyright infringement are mandatory and may command positive obligations on copyright holders. ${ }^{92}$

For the more vulnerable group among copyright users, i.e., individual users or consumers, an access to justice lens reminds us that traditional remedies before a court of law are of little avail to them, given the several obstacles that exist for individual consumers in general and copyright users in particular. The strength and value of exceptions to copyright infringement such as fair dealing or fair use are seriously undermined if a user is placed in a situation to ask permission ex ante before a court of law to exercise their right to deal fairly with a work. ${ }^{93}$

An access to justice perspective suggests that "just" copyright user rights should not so much be measured by the remedies they have against copyright holders obstructing legitimate uses of copyright works. Rather, they should be evaluated by not needing to resort to those traditional remedies before a court of law to ensure access to copyright works, on the basis of the clearer rights that will be set out for them. The more substantive rights and enabling architectures will ensure access to and enjoyment of copyright works through non-dispute means, the more we are likely to better address access to justice issues for copyright users.

\section{(iv) What reforms for copyright users?}

Exploring what the insights from access to justice literature bring to copyright user rights, in particular the wave of "demystifying law", how should we reform copyright user rights at a substantive level? What technological platforms and incentives could facilitate access to copyright works? How may we communicate rights to users more effectively, taking inspiration from the wave of "plain language" movement of access to justice? And how can we ensure greater justice for copyright users while not losing sight of a just treatment of authors and copyright holders? I propose here a

90 See above Part 2 "Copyright Users and Remedies".

91 Ibid.

92 See below iv "What reforms for copyright users?".

93 Burk and Cohen (2001, p. 61), pointing to the lack of spontaneity that ex ante procedures engender and how it would leave exercise of fair use to the privileged users with means to assess costs versus benefits of taking action. 
framework of enquiry that addresses some of these questions, at least in part, with possible avenues of legal reform to consider.

\section{- Making copyright holders' accountable for user-friendly access architectures}

In previous work, I suggested the application of general guiding principles that would advance the rights and interests of copyright users, and that should be considered by the judiciary and in future legal reform (Chapdelaine 2017, pp. 180-91). These guiding principles include (i) that some onus and responsibility need to be placed on copyright holders on how the works they make accessible accord with the rights and interests of copyright users; and (ii) the need to regulate copyright holders' commercial practices that deviate from the core objectives of copyright to encourage the creation and dissemination of works (Chapdelaine 2017, pp. 187-91). I also developed a taxonomy and hierarchy of copyright user rights, which I discuss further below in this part through an access to justice perspective. These guiding principles ask for an important adjustment in the balance that is promoted in our current copyright law system between competing interests, by leaning it more toward increased copyright user access to copyright works. The guiding principles aim at creating the right level of incentives on how copyright holders make their works accessible to copyright users in a way that is congruent with the raison d'être of the state grant of powers and privileges to copyright holders, and that minimizes the need by users to resort to ex ante remedies.

In effect, the guiding principles would alter the current so-called balance in our current copyright law by setting limits on how copyright holders may commercialize their works, as opposed to the status quo which gives a broad discretion on how copyright holders commercialize their works, to dissipate uncertainty on whether the $C C A$ allows copyright holders to override the default rules set out by the $C C A$, including exceptions to copyright infringement (Chapdelaine 2013, pp. 30, 37-38).

The guiding principles are one response to the concerns shared by scholars on the effect some mass market commercial practices have on the default rules set by copyright law to allocate powers and privileges between right holders, copyright users, keeping in mind the broader objectives of copyright to encourage the creation and dissemination of works and the greater public interest. ${ }^{94}$ Non-negotiated standard form user agreements overriding exceptions to copyright infringement, or significantly diminishing the property rights in copies of copyright works, and the deployment of technological protection measures and their impact on user rights and interests are among the commercial practices that raise these concerns. The solutions proposed include a presumption of non-enforceability of contract clauses that restrict the application of exceptions to copyright infringement, and of licences that seek to negate the personal property of users in the copies of copyright works they lawfully purchase. ${ }^{95}$ Some copyright statutes including in France, Belgium, and the UK, or regional instruments including in the European Union (EU) provide that exceptions are mandatory, or specifically single out exceptions that may not be waived by contract. ${ }^{96}$

94 The issue of how right holders' commercial practices can significantly impact on copyright law and policy has been largely commented upon. See e.g., Lemley (1999); McManis (1999); Elkin-Koren (2001) 195; Radin (Radin); De Werra (2003); Penalver and Katyal (2010, pp. 46-51).

95 Chapdelaine (2017, pp. 188-91). See Radin (2013, pp. 168-70), arguing that intellectual property user rights should not be fully alienable in the context where a standard term agreement can 'achieve widespread cancellation of user rights' which 'contributes to democratic degradations.'

96 France CPI, supra note 5 art L 122-6-1 in fine, listing exceptions to copyright infringement that are mandatory; Belgium Wetboek van economisch recht/Code de droit économique, art XI.193, listing exceptions to copyright infringement relating to computer programs that are mandatory. See also EC, Council and Parliament Directive 2009/24/EC of 23 April 2009 on the legal protection of computer programs, [2009] OJ L 111/16 [Directive 2009/24/EC] where some exceptions to copyright infringement related to computer programs cannot be limited by contract: art 5(2) and (3); UKCDPA, supra note 9, see e.g., ss 29 (4b) (fair dealing for purpose of research and private study) 29A (5) Copies for text and data analysis for non-commercial research) $30(1 \mathrm{ZA})(4)$ (quotations) $30 \mathrm{~A}(2)$ (caricature, parody or pastiche). 
The increased mass deployment of automated copyright enforcement tools to detect possible copyright infringement ${ }^{97}$ are yet another form of private ordering that raise important questions on their effects on the default rules set by copyright law to mediate between competing interests and more particularly about the rights and interests of copyright users. The deployment of large-scale automated platforms also begs the question: how to incent platform code architectures to be copyright-user friendly? What accountability and responsibility should copyright holders have towards users in that regard?

Examples abound of Copyright holders and internet platform intermediaries that use algorithms to detect possible copyright infringement. ${ }^{98}$ Those include copyright matching and filtering systems applied by internet intermediaries, such as YouTube's Content ID, which gives the option to participating right holders to block, mute or simply monitor content that is detected as potentially infringing their copyright. ${ }^{99}$

The incentives to put such detection mechanisms in place are obvious from the copyright holders' perspective: protecting their works against high volumes of copyright infringement in an efficient manner and avoiding costly and lengthy litigation (Sag 2017, pp. 39-60). For internet platform operators, while the law does not require that they actively monitor the lawfulness of copyright content that they disseminate (provided that they comply with the relevant safe harbor requirements-i.e., "notice-and take-down" provisions in the US or "notice-and-notice" provisions in Canada-) ${ }^{100}$ internet platform operators are increasingly under pressure from large right holders to set such infringement monitoring systems in place (Sag 2017, pp. 39-46).

Large scale automated right enforcement practices create favourable biases about their legitimacy and raise important issues for copyright users to the extent that they lead to false assessments of copyright infringement or narrow users' exercise of powers and privileges in cases where the alleged copyright infringement is doubtful (Sag 2017, pp. 25-29, 46-59). ${ }^{101}$ The lack of transparency and the questionable legitimacy of the outcomes of automated copyright enforcement systems may mislead consumers and the public to believe that such practices are in line with copyright law and hence eliminate in their mind the prospect of a valid claim against the obstruction to their use of a copyright work (Elkin-Koren 2016, p. 488).

Unlike copyright holders and to some extent intermediaries' push toward protecting works against copyright infringement, incentives may not be as obvious when it comes to facilitating access to legitimate uses of copyright works that are blocked through copyright holders or intermediaries' contract terms, digital locks or self-enforcement automated systems.

The lack of incentive for copyright holders to accommodate copyright user liberties and privileges suggests the need to make them accountable by imposing positive obligations on copyright holders through regulation. Daniel Burk and Julie Cohen have analysed how code architectures could promote and safeguard users' ability to exercise their privilege to make fair uses of copyright works as they are endorsed by copyright law (Burk and Cohen 2001). Maayan Perel and Niva Elkin-Koren call for greater accountability and transparency in how copyright holders deploy automated copyright enforcement

97 e.g., matching and filtering systems applied by internet intermediaries, such as YouTube's Content ID: “YouTube Help, How Content ID Works" (YouTube 2018).

98 See (Sag 2017, p. 40). On the difference between how automated copyright enforcement tools are used by right holders and by intermediaries: Ibid at 45, noting that right holders would typically have to follow the notice and take-down regime set out in the US Digital Millenium Copyright Act, Pub L No 105-304, 112 Stat 2860 (1998) [DMCA] and that intermediary platform operators of such copyright enforcement tools create an alternative regime ("DMCA plus" regime).

99 The matching and filtering system also allows copyright holders to monetize allegedly infringing videos by placing ads next to them. See (YouTube 2018).

100 Copyright Act, 17 USC, § 512; CCA, supra note 2, ss 41.25-41.27.

101 See also Elkin-Koren (2016, pp. 484-96), (raising concerns on the accuracy of automated copyright enforcement systems and making a plea for more algorithmic accountability); Lester and Pachamanova (2017) (evaluating how to measure and regulate the effectiveness of algorithms (such as "Content ID") to avoid risks of false positives of copyright infringement while protecting the interests of copyright holders). 
tools to protect their copyright works (Perel and Elkin-Koren 2016). With the preoccupation in mind of what incentive would lead right holders to set such user-convivial platforms in place, these authors' proposals point to the need for some copyright law reform imposing to varying degrees some level of obligations on copyright holders (Burk and Cohen 2001, pp. 63-70). ${ }^{102}$

Burk and Cohen proposed a "mixed fair use infrastructure" that could help achieve the goal of facilitating users' exercise of otherwise obstructed fair use of a digital work by digital locks (Burk and Cohen 2001, p. 65ff). One aspect of the regulation of code infrastructures would be that the law could require that the architecture embed a minimum automatic low level of non-controversial fair uses of copyright works (Burk and Cohen 2001, p. 65). For instance, a music provider could allow a limited number of copies of musical recordings for non-commercial use through TPMs. Burk and Cohen point out to the US Copyright Act imposing similar requirements on how technological protection measures need to be designed (Burk and Cohen 2001, p. 58). ${ }^{103}$ For uses beyond a pre-set allowance of exercises of fair use, a trusted third-party intermediary would be put in place to manage access keys (Burk and Cohen 2001, pp. 65-67). The third party intermediary should have no oversight on the legitimacy of the access prior to granting the keys, and the privacy of the users should be preserved in order to maintain the level of spontaneity and ease that are defining traits of fair use (Burk and Cohen 2001, pp. 63-64). One may question the role of the third-party intermediary if it releases keys to works without making any preliminary judgment on the lawfulness of the intended use. Burk and Cohen respond to the critique of potential under protection of copyright works by adding that information about the person having requested the key could be made available under court order and as evidence of piracy (Burk and Cohen 2001, p. 64). Copyright holders failing to make the necessary key deposits would not benefit from the legal protection the law confers to their digital locks, thereby effectively giving way to a 'right to hack' as a substitute for access through the escrowed access keys (Burk and Cohen 2001, p. 66). ${ }^{104}$

Some may take aim at the proposition that we need to create incentives for the creation of user-right friendly internet platforms. The Internet has been auspicious to users, and has ignited a user culture of sharing, adaptation and transformation of copyright works in unprecedented ways. And with this come countless instances of unlawful reproductions of copyright works. It is only natural for copyright holders, the argument goes, to protect their works through digital locks or other means such as automated copyright screening mechanisms. The law needs to support those efforts to rectify the huge de facto imbalance that favours users.

Platforms such as YouTube, Facebook, Instagram, Snapchat foster a dialogue around various creative works: music, film, photos, books and other literary works as well as the creation of new works building on earlier ones. Some of these uses of copyright works may not constitute copyright infringement either because they are a fair dealing or fair use of copyright works. ${ }^{105}$ In Canada, several of these uses could fall under the non-commercial user-generated content exception to copyright infringement that was introduced in 2012. ${ }^{106}$ While it is legitimate for copyright holders to protect their works against instances of piracy and other types of primary and secondary infringement, not placing

102 The mixed-fair-use infrastructure that they propose and which is discussed further below in this section would require changes to the US Copyright Act, 17 USC; Ibid, at 529-532, advocating mandatory minimum disclosure requirements. See also Perel and Elkin-Koren (2017) (on the inadequacy of transparency to ensure public oversight on algorithms, advocating for self-help capabilities as a more efficient means of ensuring accountability of algorithms, using online copyright enforcement algorithms as a case study).

103 Citing the Audio Home Recording Act, 17 USC $\S 1002$ (2001) regarding digital audio tape recordings and allowing the production of only one generation of perfect copies, and 17 USC $\$ 1201(\mathrm{k})(2)(2001)$, imposing certain requirement on copy-control technologies for videocassette recorders to allow time-shifting of broadcasts and cable television programming.

104 See also Mazziotti (2008, p. 220), proposing that TPMs that fail to allow the exercise of exceptions to copyright infringement should not receive legal protection.

105 CCA, supra note 2, ss 29-29.2 if it falls under the purpose of research, private study, education, parody, satire, criticism, review, or news reporting, such purposes being interpreted broadly, and if the dealing is fair: $\mathrm{CCH}$, supra note 1 at paras 47-73; US Copyright Act, supra note 102, $\$ 107$.

106 CCA, supra note 2, s 29.21 . 
any accountability on copyright holders to have built-in mechanisms that safeguard user liberties shows an important disregard of copyright users and of the objectives embedded in copyright law evidenced among others through exceptions to copyright infringement.

The model proposed by Burk and Cohen is one among others that seeks to counterbalance the detrimental effects that mass-market automated management of copyright works may have on copyright users (Perel and Elkin-Koren 2016; Parchomovsky and Weiser 2010). As "code is law"107 and that this law is now in the hands of copyright holders and in some cases, internet platform operators, the law of the state needs to step in and impose some accountability on copyright holders in counterpart to the exclusive rights that copyright confers on right holders. Promoting more transparency on the effects of copyright work management automated systems would pursue similar objectives to the ones promoted by the plain language movement of access to justice by bringing it beyond the laws of the state to the laws of the firm. ${ }^{108}$ Requiring right holders and intermediaries to notify users of their rights (reformed as proposed here) and how they may facilitate removing any obstacle to legitimate access would also facilitate maintaining a healthy equilibrium between copyright holder rights protection while acknowledging the rights of users.

In parallel to incenting the creation of online platforms that embed functionalities that facilitate greater access to copyright users, the imagination runs wild as to what other technological developments may promote and safeguard the rights of users to copyright works. Online dispute resolution platforms, either private or public, are among those that come to mind. ${ }^{109}$

\section{- Differentiating among various types of users}

Justice for users does not necessarily entail that all users should be treated equally as it would fail to consider different degrees of legitimate expectations with respect to uses of a work, as well as varying degrees of competing interests of authors and copyright holders (Chapdelaine 2017, pp. 191-202). ${ }^{110}$ In that view, "user-copy-owners" would have greater rights than "service-users" who in turn would have greater rights than "public-space-users" (Chapdelaine 2017, pp. 191-202). Starting with user-copy-owners, as the personal property owners in the copy of the copyright work, they would have the right and privilege to use the copy of the copyright work so long as their use does not have a substantial adverse effect on the exploitation or potential exploitation of the copyright work or the moral rights of the author. Copyright holders would have the correlative obligation to remove any obstacles to such use of the copyright work by the personal property owner of the copy and there would be a presumption that any contract terms or TPM that would block the use of the personal property owner of the copy would be non-enforceable. Copy-user owners would include users who should effectively be held to own a copy of the copyright work regardless of the terms of use referring to a "licence", when the contract granting access to the copyright work pertains to a one-time payment in exchange for permanent or open-ended possession of the copyright work. ${ }^{111}$ The hierarchy of user rights advocates that fairer laws and the principle of equality need to give greater recognition to the property rights of copyright users as a vehicle that allows and safeguards a fair access to copyright works. As one example, the concept of the "normal usage" of the copy of a copyright work as it exists

107 See generally, Lessig (2006).

108 See however, Perel and Elkin-Koren (2017), on the limited value of promoting transparency to hold copyright holders accountable regarding algorithms used for online copyright enforcement.

109 Rabinovich-Einy and Katsh (2017b) (on the successes and future promises for individuals of online dispute resolution either in the private sector (e.g., e-Bay) or public sector); Rabinovich-Einy and Katsh (2017a).

110 Presenting a taxonomy and hierarchy of copyright user rights based on whether the user owns a copy of the work, has a service contract with the copyright distributor, or is a public-space user (i.e., with no contractual relationship pertaining to the copyright work that the user has access to).

111 Or access to digital goods whether through a tangible copy or intangible asset: see Perzanowski and Schultz (2016, p. 180). 
in civil law jurisdictions ${ }^{112}$ would continually adapt based on changing technology, expectations and social norms, as well as the objectives of copyright law.

Service users would have the privilege to perform any acts that do not have a substantial adverse effect on the (potential) exploitation of the copyright work, and on the moral rights of the author, accompanied by a presumption that such privilege cannot be waived by contract. By the same token, TPMs should not impair the exercise of the privilege. Service users would include users who have no permanent physical control over the copy of a copyright work, such as in a rental agreement (e.g., library users) or other temporary access to copyright work (e.g., streaming service where the user has no permanent control over the copyright work they stream). Unlike for user-copy-owners, the privilege conferred on service users would not impose a blanket positive obligation on copyright holders to grant access beyond the practical limits and expectations of the service through which users experience the work, while at the same time it would allow users to perform acts that do not have substantial adverse effects on the exploitation of the work or with moral rights.

Public-space users, are those users who enjoy a copyright work (not in the public domain) without a commercial transaction with the copyright holder or its distributor. This includes works that are freely accessible through the Internet (e.g., blog posts, photographs) or in public spaces (e.g., architectural works, sculptures, and other street art). There the law should confer on public-space users the benefit of a rebuttable presumption of an implied licence (or partial abandonment of rights) to use the work in any manner that does not conflict with the commercial exploitation of the copyright work and that does not infringe moral rights. Such implied licence would respect the legitimate interests of copyright holders, while taking into account reasonable user expectations.

From an access to justice standpoint, one may criticize the hierarchy of copyright user rights proposed here, on the basis that more rights would be conferred on copyright users who own the copy of the work they use, as opposed to users who come across a work in public spaces, including texts made openly available on the Internet. If more just user rights implicate ensuring optimal access to knowledge, why should there be a difference based on whether the user owns the copy of the work or not? The short answer to this question is that justice for users and optimal access to knowledge both involve consideration for the rights and interests of authors and copyright holders. As a result, there should in my view be a different level of expectations towards authors and copyright holders when users own the copy of the work (which implicates that there was at some point in time a commercial transaction that benefited the copyright holder and distinct property rights of the user that need to be recognized) versus situations when potential users come across a work in the public sphere. In the latter case the positive obligations that could be imposed on copyright holders and authors to remove any obstacles to legitimate uses of those works would not be justified the same way it would for users owning a copy of the work. Yet, would be users of copyright works accessed through public spaces should still be entitled to make legitimate uses of the work on their own (albeit without the active help of copyright holders). The doctrine of implied licence in particular could be an important vehicle to legally endorse legitimate uses of the copyright works made available in the public sphere.

Looking at this proposed hierarchy of rights, an access to justice outlook may also question the extent to which the distinction between users having rights versus privileges (in the Hohfeldian sense of jural correlatives) matters. After all, users are free to make uses of the copyright work whether as a right or as a privilege, subject to respecting the exclusive rights of authors and copyright holders within the boundaries proposed above. Taking a closer look, the difference between conferring rights or privileges to users still matters both from the perspective of copyright users and copyright holders. Conferring specific rights on copyright users will create a correlative obligation on copyright holders to

112 For example in France and Belgium, the relevant copyright statutes provide that TPMs cannot restrain the 'normal use' (or similar concept) of a copyright work: France CPI, supra note 5, art L 331-5 (in French, libre usage); Belgium Wetboek van economisch recht/Code de droit économique, art X.291 § 4 (in French, destination normale and in Dutch, beoogde dool te gebruiken). 
facilitate adequate access where the privilege would fall short of doing so. This correlative obligation could in turn incent copyright holders to put in place infrastructures to regulate and facilitate access. ${ }^{113}$

In addition, failure by copyright holders to provide access to the work would give users traditional remedies before a court of law. On this last point, while remedies as such are limited in what they have to offer to copyright users from a broader access to justice perspective, those same remedies take a different meaning once user rights have been invigorated at the substantive level as suggested here. What's more, the possibility of legal action by copyright users (including through class actions) backed by firmer user rights as per the reform proposed here, creates a further incentive for copyright holders to act preventatively: among others by putting the proper access architecture and mechanisms in place. ${ }^{114}$

Under this hierarchy of user rights, authors and copyright holder rights and interests would be preserved by placing an outer limit to copyright user rights, namely: any substantial adverse effect that the use of the work would have on the exploitation or potential exploitation of the copyright work or, where applicable, the moral rights of the author. The concept of "substantial adverse effect on the rights of authors and copyright holders" is problematic to the extent that opinions may vary greatly on what a "substantial adverse effect" might be. A genuine attempt to look at the interests of users and copyright holders even-handedly would attenuate what is considered to be within the exclusive realm of copyright holders today, i.e., this part of their exclusive domain that limits user rights to engage with the works in a meaningful way and in accordance with the objectives of copyright law to encourage the creation and dissemination of works, while at the same time not competing with the exploitation of copyright holders' works. ${ }^{115}$ Subjecting copyright user rights to the moral rights of the author, in particular the right of attribution, ${ }^{116}$ would arguably go a long way in reconciling the interests of authors and users when they collide. Beyond the economic rights conferred by copyright to a work, authors are often as preoccupied (and in some case even more preoccupied) with being adequately acknowledged as the author of a work, than about receiving monetary compensation for someone else's use of their work.

\section{Conclusion: Moving beyond Copyright User Remedies}

What remedies copyright users have is a valid question to better understand the nature of their rights in a rights-remedies paradigm. An access to justice perspective brings the question of user rights and remedies in a different light. Even in a best-case scenario, where copyright user rights would be stronger and more clearly defined, traditional remedies before a court of law would be of limited appeal to copyright users and in particular individual consumers. At present, copyright user rights as shaped by human rights, copyright, property, contracts, sale of goods, consumer law and competition law, are weak and their contours are uncertain. They reflect inequality of treatment with the competing rights of copyright holders, a lack of safeguard for the respect of users' fundamental freedoms, potentially leading to a less than optimal access to copyright works, and this contrary to some of the primary objectives of copyright law. Given this state of affairs, the question of the remedies users have before a court of law against blocked access to copyright works is at this point in time of lesser interest, until we address more properly user rights to copyright works by strengthening them at a substantive level. This will take place by integrating public law (e.g., fundamental rights) and private law considerations (e.g., user personal property rights) in the treatment of copyright users.

Creating the right level of incentives for copyright holders to facilitate access to copyright works at a pre-dispute phase is more conducive to justice than traditional remedies before a court of law.

\footnotetext{
113 See above "Making copyright holders accountable for user-friendly access architectures".

114 Ibid.

115 In economic theory terms, this could also be referred to eliminating situations of "deadweight loss".

116 CCA, supra note 2 , ss 14.1, 17.1 .
} 
Once stronger copyright user rights will be in place, justice for copyright users will be achieved and maintained by keeping the need to resort to traditional remedies to a minimum.

This article did not discuss the importance of involving copyright user interest groups in the reform and decision-making process, one of the preoccupations brought to the fore in the "fifth wave" of "proactive access to justice". ${ }^{117}$ This is a key component to increase the chance of successfully implementing stronger copyright user rights advocated in this article. Let's hope the next wave of reform of Canadian copyright law will meet the need for an adequate and balanced representation of all constituents, and that it will let the voice be heard loud and clear of those who use, share and enjoy works of creation, those works that engage users' minds, educate, inspire, convey meaning, and make users innovate and create.

Funding: This research received no external funding.

Acknowledgments: The author thanks the participants of the Symposium on Copyright User Rights and Access to Justice, hosted by Windsor Law LTEC Lab (www.lteclab.com) in May 2017, and in particular Carys Craig, for very helpful comments on a previous version of this article, as well the two anonymous peer reviewers of this article for insightful feedback. The author also thanks Grigor Grigorian (Windsor Law, JD 2019) and Shahnaz Dhanani (Windsor Law, JD 2020) for their excellent research assistance.

Conflicts of Interest: The author declares no conflict of interest.

\section{References}

Akin Ojelabi, Lola. 2010. Improving Access to Justice through Alternative Dispute Resolution: The Role of Community Legal Centres in Victoria, Australia. Research Report. Bundoora: Faculty of Law and Management, La Trobe University.

Al-Sharieh, Saleh. 2018. Securing the Future of Copyright Users' Rights in Canada. Windsor Yearbook of Access to Justice 35: 11.

Australia Attorney General Department. 2009. Access to Justice Task force, A Strategic Framework for Access to Justice in the Federal Justice System; Sydney: Attorney General Department.

Australia Commonwealth. 2013. Law Reform Commission, Copyright and the Digital Economy; Report No 122; Sydney: ALRC.

Australian Government, Department of Communication and the Arts. 2018. Copyright Modernization Consultation Paper. Available online: https:/ /www.communications.gov.au/have-your-say/copyrightmodernisation-consultation (accessed on 19 June 2018).

Backhouse, Constance. 2005. What is Access to Justice. In Access to Justice for a New Century—The Way Forward. Edited by Julia Bass, William A. Bogart and Frederick H. Zemans. Toronto: Law Society of Upper Canada, pp. 113-46.

Bannerman, Sara. 2016. International Copyright and Access to Knowledge. Cambridge: CUP.

Bebenek, Krzysztof. 2011. Strong Wills, Weak Locks: Consumer Expectations and the DMCA Anti-circumvention Regime. Berkeley Technology Law Journal 26: 1457.

Burk, Dan L., and Julie E Cohen. 2001. Fair Use Infrastructure for Rights Management Systems. Harvard Journal of Law \& Technology 15: 41.

Cafaggi, Fabrizio, and Hans W. Micklitz, eds. 2009. New Frontiers of Consumer Protection: The Interplay between Private and Public Enforcement. Cambridge: Intersenstia.

Canada Competition Bureau. 2016. Intellectual Property Enforcement Guidelines. March 31. Available online: http:/ / www.competitionbureau.gc.ca/ eic/site/cb-bc.nsf/eng/04031.html (accessed on 31 March 2018).

Chapdelaine, Pascale. 2013. The Ambiguous Nature of Copyright Users' Rights. Intellectual Property Journal 26: 1. Chapdelaine, Pascale. 2014. The Property Attributes of Copyright. Buffalo Intellectual Property Law Journal 10: 34. Chapdelaine, Pascale. 2017. Copyright User Rights, Contracts and the Erosion of Property. Oxford: OUP.

Cobb, Kristin. 2014. The Implications of Licensing Agreements and the First Sale Doctrine on U.S. and EU Secondary Markets for Digital Goods. Duke Journal of Comparative \& International Law 24: 529.

117 See above Part 3.1 "Access to justice sphere of inquiry". 
Cohen, Julie E. 1997. A Right to Read Anonymously: A Closer Look at “Copyright Management” in Cyberspace. Connecticut Law Review 28: 981. [CrossRef]

Cohen, Julie E. 2005. The place of the User in Copyright Law. Fordham Law Review 74: 347.

Craig, Carys J. 2005. The Changing Face of Fair Dealing in Canadian Copyright Law: A Proposal for Legislative Reform. In The Public Interest: The Future of Canadian Copyright Law. Edited by Michael Geist. Toronto: Irwin Law.

Craig, Carys. 2011. Copyright, Communication and Culture: Torwards a Relational Theory of Copyright Law. Cheltenham: Edward Elgar.

Craig, Carys J. 2017. Globalizing User Rights-Talk: On Copyright Limits and Rhetorical Risks. American University International Law Review 33: 1. Available online: http:/ / digitalcommons.osgoode.yorku.ca/scholarly_works / 2666 (accessed on 18 June 2018).

D'Agostino, Giuseppina. 2008. Healing Fair Dealing? A Comparative Copyright Analysis of Canadian Fair Dealing to UK Fair Dealing and US Fair Use. McGill Law Journal 53: 309. [CrossRef]

D’Agostino, Giuseppina. 2010. Copyright, Contracts, Creators, New Media, New Rules. Cheltenham: Edward Elgar Publishing.

De Werra, Jacques. 2003. Moving beyond the Conflict between Freedom of Contract and Copyright Policies: In Search of a New Global Policy for On-Line Information Licensing Transaction. Columbia Journal of Law $\mathcal{E}$ the Arts 25: 239. Available online: https:/ / ssrn.com/abstract=2149796 (accessed on 18 June 2018).

Dedek, Helge. 2010. From Norms to Facts: The Realization of Rights in Common and Civil Private Law. McGill Law Journal 56: 77-114. [CrossRef]

Drahos, Peter, and John Braithwaite. 2002. Information Feudalism, Who Owns the Knowledge Economy? London: Earthscan.

Drassinower, Abraham. 2005. Taking User Rights Seriously. In The Public Interest: The Future of Canadian Copyright Law. Edited by Michael Geist. Toronto: Irwin Law, p. 462.

Drassinower, Abraham. 2015. What's Wrong with Copying? Cambridge: Harvard University Press, London: Harvard University Press.

Dusollier, Séverine. 2007. Droit d'auteur et protection des oeuvres dans l'univers numérique, 2nd ed. Bruxelles: Larcier.

Electronic Frontier Foundation. 2014. Unintended Consequences: Sixtenn Years under the DMCA'. Available online: https:/ / www.eff.org/wp/unintended-consequences-16-years-under-dmca (accessed on 18 June 2018).

Elkin-Koren, Niva. 2001. A Public-Regarding Approach to Contracting over Copyrights. In Expanding the Boundaries of Intellectual Property: Innovation Policy for the Knowledge Society. Edited by Rochelle Cooper Dreyfuss, Diane Leenheer Zimmerman and Harry First. Oxford: Oxford University Press.

Elkin-Koren, Niva. 2007. Making Room for Consumers under the DMCA. Berkley Technology Law Journal 22: 1119. Elkin-Koren, Niva. 2016. The New Frontiers of User Rights. American University International Law Review 32: 1.

Elkin-Koren, Niva. 2017. Copyright in a Digital Ecosystem, a User Rights Approach. In Copyright Law in an Age of Limitations and Exceptions. Edited by Ruth L. Okediji. New York: CUP.

Engle, David M. 1984. The Oven Bird's Song: Insiders, Outsiders, and Personal Injuries in an American Community. Law E Society Review 18: 551.

Flestiner, William L.F., Richard L. Abel, and Austin Sarat. 1980-1981. The Emergence and Transformation of Disputes: Naming, Blaming, Claiming. Law and Society Review 15: 631. [CrossRef]

Guibault, Lucie. 2002. Copyright Limitations and Contracts, An Analysis of the Contractual Overridability of Limitations on Copyright. The Hague: Kluwer Law International.

Geist, Michael, ed. 2010. From 'Radical Extremism' to 'Balanced Copyright': Canadian Copyright and the Digital Agenda. Toronto: Irwin Law.

Gervais, Daniel. 2004. Canadian Copyright Law Post-CCH. Intellectual Property Journal 18: 131.

Ghai, Yash, and Jill Cottrell. 2010. The rule of law and access to justice. In Marginalized Communities and Access to Justice. Edited by Yash Ghai and Jill Cottrell. New York: Routledge-Cavendish.

Harris, James W. 1996. Property and Justice. Oxford: Clarendon Press.

Heller, Michael. 2010. The Gridlock Economy: How too Much Ownership Wrecks Markets, Stops Innovation and Costs Lives. New York: Basic Books.

Hohfeld, Wesley N. 1913. Some Fundamental Legal Conceptions as Applied in Judicial Reasoning. The Yale Law Journal 23: 16-59. [CrossRef] 
Hohfeld, Wesley N. 1917. Fundamental Legal Conceptions as Applied in Judicial Reasoning. The Yale Law Journal 26: 710-70. [CrossRef]

Howe, Helena, and Jonathan Griffith, eds. 2013. Concepts of Property in Intellectual Property. Cambridge: CUP.

Hugenholtz, P. Bernt. 2001. Copyright and Freedom of Expression in Europe. In Expanding the Boundaries of Intellectual Property: Innovation Policy for the Knowledge Society. Edited by Rochelle Cooper Dreyfuss, Diane Leenheer Zimmerman and Harry First. Oxford: Oxford University Press.

Izyumenko, Elena. 2016. The Freedom of Expression Contours of Copyright in the Digital Era: A European Perspective. Journal World Intellectual Property 19: 115-30. [CrossRef]

Kapczynski, Amy. 2008. The Access to Knowledge Mobilization and the New Politics of Intellectual Property. The Yale Law Journal 117: 804. [CrossRef]

Katsh, Ethan, and Orna Rabinovich-Einy. 2017. Digital Justice, Technology and the Internet of Disputes. Oxford: OUP.

Katz, Ariel. 2013. Fair Use 2.0: The Rebirth of Fair Dealing in Canada. In The Copyright Pentalogy, How the Supreme Court of Canada Shook the Foundations of Canadian Copyright Law. Edited by Michael Geist. Ottawa: University of Ottawa Press.

Lemley, Mark A. 1999. Beyond Pre-emption: The Law and Policy of Intellectual Property Licensing. California Law Review 87: 111. [CrossRef]

Lessig, Lawrence. 2006. Code: Verion 2.0. New York: Basic Books.

Lester, Toni, and Dessislava Pachamanova. 2017. The Dilemma of False Positives: Making Content ID Algorithms More Conducive to Fostering Innovative Fair Use in Music Creation. UCLA Entertainment Law Review 24: 51.

Macdonald, Roderick A. 2005. Access to Justice in Canada Today: Scope, Scale and Ambitions. In Access to Justice for a New Century - The Way Forward. Edited by Julia Bass, William A. Bogart and Frederick H. Zemans. Toronto: Law Society of Upper Canada.

Mazziotti, Giuseppe. 2008. EU Digital Copyright Law and the End-User. Berlin: Springer-Verlag.

McManis, Charles R. 1999. The Privatization ("Shrink-Wrapping") of American Copyright Law. California Law Review 87: 173. [CrossRef]

Moyse, Pierre-Emmanuel. 2008. Kraft Canada c. Euro-Excellence: l'insoutenable légèreté du droit. McGill Law Journal 53: 741.

Netanel, Neil Weinstock. 2013. First Amendment Constraints on Copyright after Golan v. Holder. UCLA Law Review 60: 1082.

Okediji, Ruth L. 2017. Reframing International Copyright Limitations and Exceptions as Development Policy. In Copyright Law in and Age of Limitations and Exceptions. Edited by Ruth Okediji. Cambridge: Cambridge University Press.

Parchomovsky, Gideon, and Philip J. Weiser. 2010. Beyond Fair Use. Cornell Law Review 96: 91.

Pecman, John. 2016. Intellectual Property \& Competition Law: Innovation in the 4th Industrial Revolution. June 10. Available online: http:/ / www.competitionbureau.gc.ca/eic/site/cb-bc.nsf/eng/04103.html (accessed on 31 March 2018).

Penalver, Eduardo Moises, and Sonia K. Katyal. 2010. Property Outlaws. New Haven: Yale University Press.

Perel, Maayan, and Niva Elkin-Koren. 2016. Accountability in Algorithmic Enforcement: Lessons from Copyright Enforcement by online intermediaries. Stanford Technology Law Review 19: 473.

Perel, Maayan, and Niva Elkin-Koren. 2017. Black Box Tinkering: Beyond Disclosure in Algorithmic Enforcement. Florida Law Review 69: 181.

Perzanowski, Aaron, and Jason Schultz. 2016. The End of Ownership, Personal Property in the Digital Economy. Cambridge: MIT Press.

Rabinovich-Einy, Orna, and Ethan Katsh. 2017a. The New New Courts. American University Law Review 67: 165.

Rabinovich-Einy, Orna, and Ethan Katsh. 2017b. A New Relationship between Public and Private Dispute Resolution: Lessons from Online Dispute Resolution. Ohio State Journal on Dispute Resolution 32: 695.

Radin, Margaret Jane. 2003-2004. Regime Change in Intellectual Property: Superseding the Law of the State with the "Law" of the Firm. University of Ottawa Law and Technology Journal 1: 173.

Radin, Margaret Jane. 2013. Boilerplate: The Fine Print, Vanishing Rights, and the Rule of Law. Princeton: Princeton University Press.

Reynolds, Graham. 2016. Reconsidering Copyright's Constitutionality. Osgoode Hall Law Journal 53: 898. [CrossRef] Reynolds, Graham. 2017. Moving Past Michelin: Towards Judicial Reconsideration of the Intersection of Copyright and the Charter Right to Freedom of Expression. Intellectual Property Journal 30: 25. 
Sag, Matthew. 2017. Internet Safe Harbors and the Transformation of Copyright Law. Notre Dame Law Review 93: 1. Available online: https:/ / ssrn.com/abstract=2830184 (accessed on 18 June 2018).

Samuelson, Pamela, and Kathryn Hashimoto. 2017. Scholarly Concerns about a Proposed Small Copyright Claims Tribunal. October 15. Available online: https: / / ssrn.com/abstract=3060796 (accessed on 18 June 2018).

Scassa, Teresa. 2002. Intellectual Property on the Cyber-Picket Line: A Comment on British Columbia Automobile Assn v Office and Professional Employees' International Union, Local 378. Alberta Law Review 39: 934.

Scassa, Theresa. 2005. Users' Rights in the Balance: Recent Developments in Copyright law at the Supreme Court of Canada. Canadian Intellectual Property Review 22: 133.

Smith, Stephen A. 2010. Rights and Remedies: A Complex Relationship. In Taking Remedies Seriously/Les recours et les mesures de redressement: une affaire sérieuse. Edited by Robert J. Sharpe and Kent Roach. Montréal: Canadian Institute for the Administration of Justice/Institut canadien de l'administration de la justice.

Tawfik, Myra J. 2005a. International Copyright Law and Fair Dealing as a User Right. UNESCO Copyright Bulletin. Available online: http:/ / portal.unesco.org/culture/en/ev.php-URL_ID=27422\&URL_DO=DO_ TOPIC\&URL_SECTION=201.html (accessed on 18 June 2018).

Tawfik, Myra J. 2005b. International Copyright Law: W[h]ither User Rights? In The Public Interest: The Future of Canadian Copyright Law. Edited by Michael Geist. Toronto: Irwin Law, p. 66.

Tawfik, Myra. 2013. The Supreme Court of Canada and the "Fair Dealing Trilogy": Elaborating a doctrine of User Rights under Canadian Copyright Law. Alberta Law Review 51: 191.

Tawfik, Myra J. 2015. Copyright and Freedom of Expression in Canada. In Intellectual Property Law and Human Rights. Edited by Paul Torremans. Alphen aan den Rijn: Kluwer Law International.

Thompson, Marcelo. 2007. Property Enforcement or Retrogressive Measure? Copyright Reform in Canada and the Human Right of Access to Knowledge. University of Ottawa Law E Technology Journal 4: 163.

WIPO. 2013. Standing Committee for Copyright and Related Rights. Working Document Containing Comments on and Textual Suggestions towards an Appropriate International Legal Instrument (in whatever Form) on Exceptions and Limitations for Libraries and Archives. WIPO Doc. SCCR/26/3. December 16-20. Available online: http:/ / www.wipo.int/meetings/en/doc_details.jsp?doc_id=242388 (accessed on 10 April 2018).

World Intellectual Property Organization. 2018. Development Agenda for WIPO. Available online: http:/ / www. wipo.int/ip-development/en/agenda/ (accessed on 31 March 2018).

Wright, David. 2010. Remedies. Annandale: The Federation Press.

YouTube. 2018. YouTube Help, How Content ID Works. Available online: https:/ /support.google.com/youtube/ answer /2797370?hl=en (accessed on 31 March 2018). 